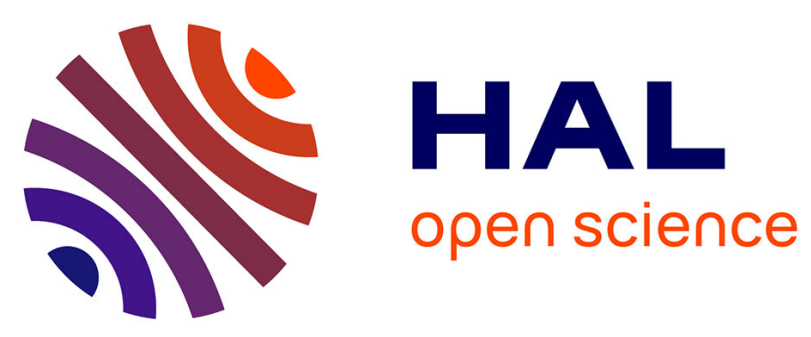

\title{
Diaphragm Involvement
}

Boris Jung, Stefan Matecki, Samir Jaber

\section{To cite this version:}

Boris Jung, Stefan Matecki, Samir Jaber. Diaphragm Involvement. Post-Intensive Care Syndrome, 2020, pp.101-107, 2020, 10.1007/978-3-030-24250-3_7 . hal-02280957

\section{HAL Id: hal-02280957 https://hal.science/hal-02280957}

Submitted on 24 Nov 2021

HAL is a multi-disciplinary open access archive for the deposit and dissemination of scientific research documents, whether they are published or not. The documents may come from teaching and research institutions in France or abroad, or from public or private research centers.
L'archive ouverte pluridisciplinaire HAL, est destinée au dépôt et à la diffusion de documents scientifiques de niveau recherche, publiés ou non, émanant des établissements d'enseignement et de recherche français ou étrangers, des laboratoires publics ou privés. 
Post-Intensive Care Syndrome, 2020 pp 101-107, pp.101-107, 2020, (10.1007/978-

3-030-24250-3_7>

\title{
Diaphragm Involvement
}

\author{
Boris Jung, Stefan Matecki, and Samir Jaber
}

7.1 Introduction -

7.2 Respiratory Muscles' Dysfunction in the ICU:Causes -

7.3 Respiratory Muscles' Dysfunction in the ICU:Pathophysiology $\quad-103$

7.4 Respiratory Muscles' Dysfunction in the ICU:Diagnosis -103

7.5 Respiratory Muscles' Dysfunction in the ICU:Management $\quad-104$

7.6 Respiratory Muscles' Dysfunction in the ICUand PICS -105

Learning Objectives

Main causes and pathophysiological keypoints of diaphragmatic dysfunction in the ICU

To diagnose the diaphragmatic dysfunction

To list the available countermeasures to limit the extent of diaphragmatic dysfunction

\subsection{Introduction}

Reduced mortality and the increasing prevalence of critical illness have resulted in a large and increasing numbers of survivors. However, survivors of critical illness can undergo profound changes in their lives as a result of their intensive care unit (ICU) stay. These changes, regrouped under the term post intensive care syndrome (PICS), are the consequences of physical [1], cognitive [2], and psychological [3] sequelae of the acute illness and the preICU comorbidities. Among these changes, pulmonary function has been studied, mostly following acute respiratory distress syndrome (ARDS) $[4,5]$ as well as other organs and functions, but the literature about the impact of critical illness on specifically the respiratory muscles and the diaphragm is lacking. The purpose of this review is to describe the impact of critical illness on the respiratory muscles' function in both the acute and the long-term periods as piece of the PICS puzzle.

\subsection{Respiratory Muscles' Dysfunction in the ICU: Causes}

Respiratory muscles' dysfunction in the ICU is multifactorial. In 1892, Osler already described a "rapid loss of flesh" in prolonged sepsis. Years after, Hussain et al. showed that ventilator failure in Escherichia Coli septic shock in dogs was the consequence of the fatigue of the respiratory muscles highlighting the strong deleterious impact of sepsis on respiratory muscles' contractility assessed by electromyogram [6]. The link between sepsis and respiratory muscles' dysfunction has been confirmed in multiple animal and human studies [7-9]. Mechanical ventilation (MV) by itself has been reported to be associated with 
diaphragm atrophy, and the first report was published in 1988 in 39 neonates or infants [10]. This condition was secondary named "Ventilator Induced Diaphragmatic Dysfunction" (VIDD) by Vassilakopoulos and Petrof [11]. Again, numerous animal studies have explored the cellular mechanisms linking controlled mechanical ventilation and VIDD, and human studies confirmed the animal findings [7, 9, 12-15] using human diaphragmatic biopsies mostly in organ donors. Eccentric contractions (contraction when the muscle lengthens) for instance when patients and ventilator are not synchronized may also generate diaphragm injuries, although the clinical evidence for this phenomenon is poor. Spontaneous breathing can also be associated with diaphragmatic dysfunction. Excessive loading or prolonged and intense resistive loading during acute respiratory failure may indeed be associated with selfinflicted respiratory muscles' injuries $[6,16]$. Besides these two major causes (sepsis and mechanical ventilation) of respiratory muscles' dysfunction, several other acute cofactors contribute. Abdominal or thoracic surgery, neuromyotoxic drugs (myorelaxants, high dose of steroids, aminoglycosides, linezolid), hypophosphoremia, hypokalemia, prolonged hyperglycemia, malnutrition, and renal failure have been associated with respiratory muscles' dysfunction [9, 17-19].

Take Home Messages

Diaphragmatic dysfunction occurs rapidly and often in the critically ill

It results from a myriad of phenomena and implicates both a rapid loss of force without loss of muscle mass and a delayed imbalance between an exaggerate proteolysis and an impaired protein synthesis generating further loss of muscle mass and force generation

Maintaining spontaneous ventilation, avoiding neuromyotoxic drugs, and maintaining electrolytes and glucose control are the most usual ways to limit the generation of diaphragmatic dysfunction in the critically ill

Temporary diaphragmatic pacing represents an interesting way of research

\subsection{Respiratory Muscles' Dysfunction in the ICU: Pathophysiology}

Systemic and local muscular inflammation especially during sepsis, sympathetic nervous system activation [20], muscle inactivity [21], metabolic oversupply (diaphragm is exposed to excessive supply of energetic substrates relative to its metabolic needs which is very low when inactive) [15], and insulin resistance [22] are observed in the respiratory muscles during the acute phase of critical illness. Consequently, several cellular pathways are activated or suppressed. Initial consequences involve contraction/relaxation homeostasis impairment and type 1 ryanodine receptor posttransductional oxidation and nitrosylation. Such modifications of the ryanodine receptor lead to calcium leak from the sarcoplasmic reticulum to the cytosol [20] activating calcium-dependent proteases. Mitochondrial dysfunction secondary to metabolic oversupply leading to reactive oxygen species release, mitochondria dynamics impairment, and further proteolysis activation has also been reported as an early phenomenon in VIDD [15]. Downstream of these early phenomena, not only excessive proteolysis (through the calpains, caspase 3, and the ubiquitin proteasome system) but also protein synthesis impairment (because of Insulin Growth Factor, AKT, and FOXO pathway inhibition) has been demonstrated [17, 18]. Autophagy, a self-degradative process important in response to nutrient stress and cell homeostasis impairment is then activated and is perceived as a physiologic response helping the cell for clearing damages organelles [23]. At the end of the road, all of these modifications lead to muscle atrophy, fibrosis, and loss of force. 


\subsection{Respiratory Muscles' Dysfunction in the ICU: Diagnosis}

Although the purpose of the chapter is to describe the diaphragm involvement in the PICS, tools that can be used to diagnose inspiratory muscles' dysfunction may be useful to evaluate the diaphragm function after ICU discharge. Inspiratory muscles' dysfunction can be diagnosed by performing pulmonary function tests sometimes at the bedside or more often in a pulmonary lab (e.g. sniff test) [24]. Surface electromyography has been suggested to evaluate diaphragm function although not being used in routine practice. Recently, ultrasonography of the diaphragm has been developed and several measures can be performed. Thickness of the diaphragm, using a $10 \mathrm{MHz}$ probe in the zone of apposition of the diaphragm to the rib cage, can be measured and is a surrogate of the diaphragm atrophy [25]. It decreases with the duration of mechanical ventilation [26], although reports suggest that it may increase [27] in some patients potentially because of muscle swelling and injury. Diaphragm excursion can be measured using a 3.5-5 MHz phased array probe. The probe is placed immediately below the right or left costal margin in the mid-clavicular line or in the right or left anterior axillary line and is directed medially and dorsally, so that the ultrasound beam reaches perpendicularly the posterior third of the corresponding hemi-diaphragm [25]. Diaphragm excursion has been suggested to be a surrogate of vital capacity but depends on the patient's motivation. Using the same window, thickening fraction can be evaluated as a surrogate of force production during quiet or forced breathing. Again, this measurement depends on the patient's motivation. No study has described the diaphragm recovery following critical illness using the ultrasound technique. The usual threshold values to define diaphragmatic atrophy are:

End expiratory thickness below $2 \mathrm{~mm}$ or a drop of more than $20 \%$ compared to baseline thickness [26, 27]

Diaphragmatic excursion during calm and spontaneous breathing lower than 10-15 $\mathrm{mm}$ [28]

Diaphragmatic thickening fraction during calm and spontaneous breathing lower than 20$30 \%$ [29-31]

The gold-standard measurement in the intubated patient requires the use of bilateral anterior magnetic stimulation of the phrenic nerves and the measurement of transdiaphragmatic pressure using a double balloon (esophagus and gastric) probe [7, 13, 32]. This technique allows a measurement without the patient's participation, and a threshold of 11 $\mathrm{cmH} 2 \mathrm{O}$ has been suggested to diagnose diaphragmatic dysfunction $[7,13,33]$. This technique in the non-intubated patient is much more difficult because of the necessity to avoid any leak (one should then use both a nasal clip and a mouth piece) during stimulation.

\subsection{Respiratory Muscles' Dysfunction in the ICU: Management}

Besides the causal treatment (e.g. sepsis), the intensivist can minimize the impact of the critical illness on the diaphragm function. By promoting spontaneous breathing during $\mathrm{MV}$, one can both limit the risk of metabolic oversupply and limit the risk of inactivityassociated atrophy [34]. Muscle contractile activity may also increase the diaphragm antioxidant capacity's release, limiting in theory the risk of the ryanodine receptor oxidation and the activation of the proteolysis cascade [35]. Eccentric contraction and excessive loading during spontaneous breathing should however be taken into account, and to date it is not completely sure whether maintaining spontaneous breathing in extreme situations such as acute respiratory distress syndrome is beneficial or deleterious for the diaphragm. Inspiratory muscle training during the weaning period has been sparsely evaluated, and to date there is a lack of evidence to promote such initiative in the routine care martin). 
Although several drugs that inhibit the proteolysis cascade and/or promote the protein synthesis pathway have been tested in animal models, a few drugs have been evaluated in humans. To date, no drug has been approved to prevent or to treat diaphragmatic dysfunction in the critically ill. Theophylline and levosimendan [36] have demonstrated beneficial effects on diaphragm contractile activity, but these results are still preliminary. Temporary diaphragmatic pacing has been recently evaluated as a method to limit the extent of diaphragmatic loss of force production. Diaphragmatic pacing can be achieved by direct implantation of electrodes in the diaphragm [37], by hooking the phrenic nerves during a surgical procedure $[38,39]$, or more recently by a transvenous (superior vena cava) stimulator $[40,41]$. In animals, diaphragmatic pacing has been associated with the restoration of the proteolysis/protein synthesis balance [38] and less fiber atrophy [40] in a VIDD model. In humans, diaphragm electrodes can be surgically placed in the diaphragm $[42,43]$ during a laparoscopy or during a thoracic surgery [44]. Phrenic nerves can be hooked during cardiac surgery, and diaphragm pacing has been associated with an improvement in mitochondrial physiology and with less oxidative stress in the diaphragm [39, 45]. Diaphragmatic stimulation can also be achieved by transvenous stimulation using a central venous catheter [40]. Diaphragm capture was evaluated in 23 patients and could reduce the pressure time product from $10 \%$ to $48 \%$ without any serious adverse event [41].

\subsection{Respiratory Muscles' Dysfunction in the ICU and PICS}

Six- and 12-month limb muscle weakness and functional impairment have been described following critical illness $[1,46]$ as well as altered pulmonary function tests, persistent hypoxemia, and incapacity to exercise [5]. Despite strong evidence showing that respiratory muscles do also show persistent weakness and ultrastructural alterations months after ICU discharge, it is very likely that respiratory muscles' weakness plays a role in the PICS picture. The involvement of the diaphragm should be investigated specifically in the next few years.

\section{References}

1. Herridge MS, Chu LM, Matte A, Tomlinson G, Chan L, Thomas C, et al. The RECOVER program: disability risk groups and 1-year outcome after 7 or more days of mechanical ventilation. Am J Respir Crit Care Med. 2016;194(7):831-44.

2. Hopkins RO, Jackson JC. Short- and long-term cognitive outcomes in intensive care unit survivors. Clin Chest Med. 2009;30(1):143-53, ix

3. Hopkins RO, Weaver LK, Collingridge D, Parkinson RB, Chan KJ, Orme JF. Two-year cognitive, emotional, and quality-of-life outcomes in acute respiratory distress syndrome. Am J Respir Crit Care Med.2005;171(4):340-7.

4. Herridge MS, Tansey CM, Matté A, Tomlinson G, Diaz-Granados N, Cooper A, et al. Functional disability 5 years after acute respiratory distress syndrome. N Engl J Med. 2011;364(14):1293-304.

5. Herridge MS, Cheung AM, Tansey CM, Matte-Martyn A, Diaz-Granados N, Al-Saidi F, et al. One-year outcomes in survivors of the acute respiratory distress syndrome. N Engl J Med. 2003;348(8):683-93.

6. Hussain SN, Simkus G, Roussos C. Respiratory muscle fatigue: a cause of ventilatory failure in septic shock. J Appl Physiol Bethesda Md 1985. 1985;58(6):2033-40.

7. Demoule A, Jung B, Prodanovic H, Molinari N, Chanques G, Coirault C, et al. Diaphragm dysfunction on admission to the intensive care unit. Prevalence, risk factors, and prognostic impact-a prospective study. Am J Respir Crit Care Med. 2013;188(2):213-9. 
8. Demoule A, Molinari N, Jung B, Prodanovic H, Chanques G, Matecki S, et al. Patterns of diaphragmfunction in critically ill patients receiving prolonged mechanical ventilation: a prospective longitudinal study. Ann Intensive Care. 2016;6(1):75.

9. Supinski GS, Callahan LA. Diaphragm weakness in mechanically ventilated critically ill patients. Crit Care Lond Engl. 2013;17(3):R120.

10. Knisely AS, Leal SM, Singer DB. Abnormalities of diaphragmatic muscle in neonates with ventilated lungs. J Pediatr. 1988;113(6):1074-7.

11. Vassilakopoulos T, Petrof BJ. Ventilator-induced diaphragmatic dysfunction. Am J Respir Crit Care Med. 2004;169(3):336-41.

12. Levine S, Nguyen T, Taylor N, Friscia ME, Budak MT, Rothenberg P, et al. Rapid disuse atrophy of diaphragm fibers in mechanically ventilated humans. N Engl J Med.

2008;358(13):1327-35.

13. Jaber S, Petrof BJ, Jung B, Chanques G, Berthet J-P, Rabuel C, et al. Rapidly progressive diaphragmatic weakness and injury during mechanical ventilation in humans. Am J Respir Crit Care Med. 2011;183(3):364-71.

14. Hussain SNA, Mofarrahi M, Sigala I, Kim HC, Vassilakopoulos T, Maltais F, et al.

Mechanical ventilation-induced diaphragm disuse in humans triggers autophagy. Am J Respir Crit Care Med. 2010;182(11):1377-86.

15. Picard M, Jung B, Liang F, Azuelos I, Hussain S, Goldberg P, et al. Mitochondrial dysfunction and lipid accumulation in the human diaphragm during mechanical ventilation.

Am J Respir Crit Care Med. 2012;186(11):1140-9.

16. Orozco-Levi M, Lloreta J, Minguella J, Serrano S, Broquetas JM, Gea J. Injury of the human diaphragm associated with exertion and chronic obstructive pulmonary disease. Am J Respir Crit Care Med. 2001;164(9):1734-9.

17. Jaber S, Jung B, Matecki S, Petrof BJ. Clinical review: ventilator-induced diaphragmatic dysfunction- -human studies confirm animal model findings! Crit Care Lond Engl.

2011;15(2):206.

18. Petrof BJ, Jaber S, Matecki S. Ventilator-induced diaphragmatic dysfunction. Curr Opin Crit Care. 2010;16(1):19-25.

19. Dres M, Goligher EC, Heunks LMA, Brochard LJ. Critical illness-associated diaphragm weakness. Intensive Care Med. 2017;43(10):1441-52.

20. Matecki S, Dridi H, Jung B, Saint N, Reiken SR, Scheuermann V, et al. Leaky ryanodine receptors contribute to diaphragmatic weakness during mechanical ventilation. Proc Natl Acad Sci U S A. 2016;113(32):9069-74.

21. Powers SK, Kavazis AN, Levine S. Prolonged mechanical ventilation alters diaphragmatic structure and function. Crit Care Med. 2009;37:S347-53.

22. Weber-Carstens S, Schneider J, Wollersheim T, Assmann A, Bierbrauer J, Marg A, et al. Critical illness myopathy and GLUT4: significance of insulin and muscle contraction. Am J Respir Crit Care Med. 2013;187(4):387-96.

23. Azuelos I, Jung B, Picard M, Liang F, Li T, Lemaire C, et al. Relationship between autophagy and ventilator-induced diaphragmatic dysfunction. Anesthesiology.

2015;122(6):1349-61.

24. American Thoracic Society/European Respiratory Society. ATS/ERS statement on respiratory muscle testing. Am J Respir Crit Care Med. 2002;166(4):518-624.

25. Matamis D, Soilemezi E, Tsagourias M, Akoumianaki E, Dimassi S, Boroli F, et al. Sonographic evaluation of the diaphragm in critically ill patients. Technique and clinical applications. Intensive Care Med. 2013;39(5):801-10.

26. Grosu HB, Lee YI, Lee J, Eden E, Eikermann M, Rose KM. Diaphragm muscle thinning in patients who are mechanically ventilated. Chest. 2012;142(6):1455-60. 
27. Goligher EC, Fan E, Herridge MS, Murray A, Vorona S, Brace D, et al. Evolution of diaphragm thickness during mechanical ventilation: impact of inspiratory effort. Am J Respir Crit Care Med. 2015;192: 1080-8.

28. Kim WY, Suh HJ, Hong SB, Koh Y, Lim CM. Diaphragm dysfunction assessed by ultrasonography: influence on weaning from mechanical ventilation*. Crit Care Med. 2011;39(12):2627-30.

29. Jung B, Moury PH, Mahul M, de Jong A, Galia F, Prades A, et al. Diaphragmatic dysfunction in patients with ICU-acquired weakness and its impact on extubation failure. Intensive Care Med. 2016;42(5): 853-61.

30. DiNino E, Gartman EJ, Sethi JM, McCool FD. Diaphragm ultrasound as a predictor of successful extubation from mechanical ventilation. Thorax. 2014;69(5):431-5. 